кандидат філософських наук, доцент

(Житомирський державний університет імені Івана Франка)

osokol 83@ukr. net

ORCID: $0000-000 \overline{3}-2228-3040$

\title{
ХРИСТОЛОГІЧНІ КОНЦЕПЦІЇ У ВЧЕННЯХ ЛЮТЕРАНСЬКОЇ ТА ЦВІНГЛІАНСЬКОЇ ТЕЧІЯХ
}

У статті досліджено основні положення христологічних доктрин лютеранства та ивінгліанства, важливо відзначити їх вплив на подальшу розбудову вчення про Ісуса Христа в межах інших течій раннього протестантизму. Доведено, що головним джерелом лютеранської христології є доктрина виправдання вірою, яка розкриває сотеріологію протестантизму. У ивінгліанстві вчення про Ісуса Христа перебуває у площині сотеріології, яка має христоцентричну спрямованість, та конщепиії передвизначеності.

Ключові слова: христологія, сотеріологія, есхатологія, лютеранство, ивінгліанство, протестантизм, тріадологія.

Постановка проблеми. Ключові положення ранньохристиянської христології знайшли відображення у систематизованому теологічному вченні про особу Ісуса Христа Римо-Католицької і Православної церков. Однак, в умовах реформаційних процесів у Європі та формування капіталістичних відносин, основні положення христології були трансформовані під теологію протестантизму, який охоплює значну кількість самостійних віросповідань. Зауважимо, що теологія ранньопротестантських течій у лаконічній формі грунтувалася на двох загальних постулатах: 1) Джерело віри - Святе Письмо (святоотцівська богословська спадщина була відкинута або спростована у процесі дискусій); 2) Спасіння людини залежить лише від віри (заперечується значення ритуалів та добрих справ). Це зумовило домінування у протестантизмі, на противагу догматичній теології католицизму і православ'я, історико-критичного способу мислення, в межах якого мислителі з обережністю ставилися до традиції та досвіду.

Аналіз наукових досліджень і публікацій. Христологія, як феномен духовних надбань суспільства, містить складний комплексний характер аналізу трансформації його провідних компонентів. На перший погляд, предмет роботи достатньо відомий і досліджений у світовій історіографії. Зарубіжна та вітчизняна наука накопичили великий фактичний матеріал, присвячений різним питанням христології, які становлять основу сучасного вивчення християнських конфесій. Однак, здебільшого в представлених працях особа Ісуса Христа піддається численним богословським тлумаченням. Натомість, релігієзнавчий аналіз христологічної доктрини в царині історії релігії, філософії та богослов'я досі не здійснювався. Певні спроби осягнути цей феномен та його історію зробили лише історики філософії.

Метою статті $\epsilon$ відмежування у протестантських догматичних системах конфесійних форм христології. Більшість протестантів поділяють загальнохристиянські положення про тріадологію й Ісуса Христа як Боголюдину, однак заперечують католицький підхід до осмислення тайни Ісуса Христа. Інші протестантські теологи поділяють христологічну доктрину антитринітаріїв, які вважають, що Христос за своєю природою не $\epsilon$ Божественною Істотою, але піднесений до стану Божественності Отцем.

Виклад основного матеріалу. Окреслюючи передумови становлення христології ранньопротестантських течій, зауважимо, що ії розвиток пройшов через трансформацією світоглядноморальних цінностей періоду Реформації у Західній Європі. У висвітленні Реформації В. Нічик відзначає головні особливості цього руху, який: "1) має масовий антифеодальний характер; 2) здійснює свої секуляризаційні завдання під гаслами боротьби за істинну віру; 3) ідеалізує й намагається відродити первісне християнство через організацію громад, заснованих на засадах рівності, братерства, любові до ближнього; 4) підносить індивідуально-духовне начало в людині, якому протиставляє матеріальний тілесний світ зла, розуміючи під ним феодальне суспільство його моральні й соціальні вади" [1: 69]. Беззаперечно, всі ці ознаки потрібно розглядати в єдності.

У межах протестантизму Реформація представлена двома формами - магістерська та радикальна. До першої С. Головащенко відносить лютеранство, кальвінізм, цвінгліанство та армініанство, натомість до другої - анабаптизм, пієтизм і ранній баптизм [2: 175]. Авторську класифікацію радикальної Реформації пропонує С. Санніков, виокремлюючи три напрямки: 1) містичний (Т. Мюнцер); 2) раціоналістичний або антитринітарний (Ф. Социн, М. Сервет); 3) центристський (анабаптизм, меннонізм) [3:231-237]. Зважаючи на інституційно-організаційні виміри раннього протестантизму, відзначимо у контексті методології конфесійні особливості христологічних систем, які вибудовувалися на різних основах.

На підставі цього слід зробити висновок, що христологія ранньопротестантських течій має як спільні ознаки, так і особливості. Відзначимо, що представники раннього протестантизму в ученні про Ісуса Христа акцентували увагу на сотеріологічному аспекті, який знайшов відображення у посланнях 
апостолів Петра і Павла. На нашу думку, такий підхід у протестантизмі зумовлений кардинальним переосмисленням сенсу земного буття, коли людина мусить постійно самовдосконалюватися i вирішувати земні проблеми через служіння Богу. Тому в нашому дослідженні ми будемо звертати особливу увагу на сотеріологічні ідеї в христологічному контексті.

Аналіз христологічних концепцій ранньопротестантських течій ми розпочнемо з лютеранства i поглядів Мартіна Лютера на особу Ісуса Христа. Традиційно в релігієзнавстві безпосереднім початком Реформації вважають протест М. Лютера проти продажі індульгенцій католицькими священнослужителями та публікацію 95-ти тез. Христологічна доктрина німецького реформатора грунтувалася на постановах Вселенських соборів про особу Ісуса Христа. Наведемо головні положення христології Лютера, відображені в тезисному документі: "Син Божий рівний й єдиносущий Отцю, Він істинний Бог, не лише за ім'ям, усиновленням чи особливою милістю, але й за сутністю і природою... Ми віруємо, що вічний Син вічного Отця став Сином Людським... Наш Господь Ісус Христос мав душу 3 розумом і тіло з відчуттями... Ми визнаємо, що в Ісусові Христі було дві природи - Божественна й людська; ці дві природи були так з'єднані в одній Особистості, що ми поклоняємося одному Христу, а не двом... Ми не вчимо, що Божественна природа в Христі страждала, і що Христос за Своєю людською природою присутній у кожному місці. Ми не думаємо, що тіло Христа перестало бути справжнім після Його прославлення або що Він обожнився так, що усунув Свої якості, що стосуються тіла й душі, і став повністю Божественним за природою та однієї тільки сутністю" [4: 134].

Як ми зауважували, вже в доктрині про виправдання вірою у контексті роздумів про спасіння людини М. Лютер вкладає новий зміст у викупну смерть Христа через "вчинення правосуддя". Сотеріологія німецького реформатора, яка базувалася на Посланні до римлян апостола Павла, визначала три кроки на шляху до спасіння: 1) людина рятується лише вірою; 2) набуття віри можливе через милість Бога; 3) єдиним авторитетом віри є Святе Письмо.

Однак, на відміну від католиків і православних, лютеранство запропонувало незвичайне осмислення процесу Втілення Христа, яке визначило всю подальшу спрямованість протестантської теології. Незважаючи на критику католицької теології загалом, і сотеріології зокрема, лютеранство, в особі М. Лютера, використало концепцію заслуги та компенсації Ансельма Кентерберійського для побудови власної сотеріології. При порівняння двох учень, можна чітко простежити їх концептуальний зв'язок.

Згідно з Ансельмом, Бог не може повернути людину до первозданного стану без задоволення з боку грішника - сатисфакції. Справедливість Бога вимагає від людини конкретних вчинків, які відшкодують Його гідність, підважену гріхами людини. Людина привносить певний надлишок, компенсуючи саму образу, заподіяну фактом ушкодження своєї сутності. Ансельм вважає гріховний вчинок не значущим для людини, однак щодо Бога він є порушенням Його волі. Кентерберійський запропонував і шляхи спокутування людиною своєї образи перед Богом: 1) покарання; 2) вблаготворення добрими справи. На думку Ансельма Кентерберійського, покарання не залучить людину до блаженства, адже гідність Бога відновиться без згоди творіння, що суперечить божественному замислу. Бог обирає інший шлях. Якщо гріх є сильною образою Бога, тоді відшкодування має перевищувати саму провину. Однак, нескінченість не може бути перевищеною людиною через ii природу, тому такий акт може здійснити лише Боголюдина. Смерть Ісуса була добровільним рішенням, від якого Він не відмовився і яка задовольнила Бога. Таким чином, Ансельм Кентерберійський заперечував спасіння як швидкоплинну подію, натомість стверджуючи, що сотеріологічне значення має все земне життя Христа.

Подібно до концепції Кентерберійського, Лютер також визначає два способи спокути: 1) прощення; 2) зараховування віри в праведність. Таким чином, виправдання можна трактувати як діяння Боже, яким Він знімає з віруючого осуд і звільняє його від вини та приписує Христову доброчинність. Однак, концепція виправдання зазнала у подальшому трансформації, i, якщо, в ранній інтерпретації, будь-яка людина за власним бажанням могла врятуватися [5: 120], то пізніше все залежало від віри людини. Зазначимо, який зміст вкладав Лютер у поняття "віра": 1) віра має лише індивідуальний характер; 2) впевненість у Божественному зобов'язанні; 3) єдність людини з Христом. При цьому віра має виражатися у вчинках, що є свідченням з'єднання з Христом [5: 124-130]. Особливу увагу Лютер звертає на співвідношення віри та вчинків. На його думку, саме діяння людини є результатом віри. Порівнюючи розуміння віри Томою Аквінським і Мартіном Лютером, стає очевидна їх відмінність. Поняття віри в Аквіната пов'язане безпосередньо із Богом, натомість лютеранське осмислення має христологічний характер. Подібний процес обумовлений тим, що віра поєднує людину з Христом та виконання Богом Свого зобов'язання перед нею, свідченням чого стало Перше пришестя Христа.

На відмінну від Ансельма Кентерберійського, Лютер показав в особі розп'ятого Христа, послуговуючись філософським предикатом непізнаванності й трансцендентності Бога, справжнього Бога. Головна ідея зводилася до того, що Бог як Справедливий Суддя повинен покарати людину за ï гріхи. Однак, через свою любов до людства Він віддає на страту Свого Сина, Який повинен сплатити викуп за провину Адама. Син Божий проходить шлях від Боговтілення до Воскресіння приносячи Себе в жертву Отцю за гріхи людей, отримуючи Божественне прощення як винагороду за страждання. Підтвердження 
цієї гіпотези Лютер знаходить у Святому Письмі: "Христос відкупив нас від прокляття Закону, ставши за нас прокляттям, бо написано: Проклят усякий, хто висить на дереві" (Галатів 3:13). Таким чином, в інтерпретації лютеранства, Христове Відкуплення виправдовує людину і переносить проблему на Бога. Цей принцип дістав назву solagratia "лише милість", який Лютер запозичив у апостола Павла [2: 183]. Тому доктрина виправдання у лютеранстві зорієнтована на спасіння, що можливе лише через милість, й це історично наперед визначено.

Людина, за вченням лютеранства, після розп'яття Христа залишалася гріховною, однак, Бог пробачив iii сутність. Лютер переконував, що людина, яку Христос не зміг змінити, не потребує нових зусиль: "Якщо ти віриш у ці фундаментальні істини християнства, що Ісус звершив для тебе особисто, то цього достатньо для спасіння" [6: 70]. На його думку, людина лише тоді починає вірити в Христа, коли бачить у Ньому своє спасіння. Таким чином, правдива віра в Христа підносить Його до власної екзистенції. Христове Відкуплення сталося заради спасіння людини, який вона може прийняти лише на основі віри: "Віра є Божественна справа в нас, яка змінює і відроджує нас, умертвляючи в нас стародавнього Адама, вона робить нас зовсім іншими людьми по серцю, розуму, почуттю..." [7: 237-238]. Ця теза є свідченням трансформації світоглядних поглядів Лютера. Якщо у доктрині виправдання вірою він наголошував на активній діяльності людини в процесі спасіння, то у подальших працях німецький реформатор висунув ідею, що доля людини не залежить від добрих справ, оскільки вона задарма отримує Божу милість через віру.

Таємниця відкуплення стала причиною лютеранського переконання у нероздільній єдності в особі Логосу Божественної і людської природи. Подібне трактування призвело до перенесення Божественної властивості всюдисущості на людську природу. 3 позиції католицизму і православ'я всюдисущість поділяється на трансцендентність та іманентність Бога. Однак, така всюдисущість, на думку Лютера, видається парадоксом через обмеженість людського розуму, яку потрібно сприймати лише на віру. Аналізуючи христологічні міркування лютеранства, В. Каспер зауважує на філософській спекуляції принципом "взаємоспілкування природних властивостей" ("communicatio idiomatum"), переносячи людські якості Христа на Божественну природу. Німецький кардинал переконаний, що вчення про Христа призводить до повної трансформації християнської христологічної доктрини, незважаючи на те, що "Лютер приймає давню христологію, проте розставляє у ній нові акценти. Він не порушує питання, яким чином можна узгодити поняття Бога і людини або ким є Бог і людина. Так, всі висловлювання про властивості Бога Лютер переносить на людську природу, яка бере участь у всюдисущості Божественної природи. I навпаки - Божественна природа бере участь у приниженні людської природи, ії стражданні та смерті" [8: 247].

Концепція Лютера фактично спростовувала христологічні надбання святоотцівської спадщини, оскільки заперечувала висхідну ідею поєднання Божественної і людської природи в Христі як необхідний акт у процесі спасіння. Натомість лютеранське вчення прирівняло іпостасне з'єднання двох природ у Христі з актом поєднання Сина Божого з гріхом. Тому, гріховна природа людини настільки віддалила Бога від свого творіння, що лише компенсація могла відшкодувати Його честь. Завдяки Христу, Бог змилувався над людиною, однак їі гріховність не зміг змінити.

Беззаперечно, великим здобутком лютеранської христології стало визнання віри найбільшою цінністю на шляху до спасіння людини. Нехтування вірою, залишає людину в гріховному стані, який наперед визначає долю людини, позбавленої Божої милості. Смерть Христа заради спасіння стала даром від Бога, яким людина нехтує.

Ставлення католицизму до доктрини Лютера виправдання вірою було викладено на Дев'ятнадцятому Вселенському (Трідентському) соборі в "Декреті про виправдання". Відзначимо, що спеціальні комісії собору повинні були дати науково-богословську відповідь на основі Святого Письма та праць Отців і Вчителів Церкви на суть виправдання, не порушуючи питань жертви Христа, заслуги та відплати [9: 345-360]. Тому "Декрет про виправдання" в шістнадцяти главах і тридцяти трьох канонах здійснює порівняльний аналіз основних засад католицької та лютеранської христології з цього питання.

Визначимо методологічний підхід лютеранської христології у зазначеному документі: 1. Рятівний задум Бога: безсилля пропащої людини; спокутне Діяння Христа; розподіл Спокути; 2. Здійснення цього задуму: первинне виправдання (шлях виправдання, визначений Богом; приготування людини, в якій беруть участь природа і благодать; природа і причини виправдання; відношення між вірою та виправданням, особливо в протиставленні думці протестантів); стан виправдання (зростання благодаті через добрі справи; необхідність і можливість дотримання заповідей; благодать наполегливості, завзятості); вторинне виправдання (Таїнство примирення, відмінне від первинного виправдання при Таїнстві Хрещення; необхідність Таїнства Примирення, бо благодать втрачається не лише через втрату віри, але і через кожен смертний гріх); заслуга добрих діянь.

На відмінну від Лютера, який у христологічних міркуваннях абсолютизував принцип "виправдання", інший лідер реформації Ульріх Цвінглі розвивав пневматичну проблематику в ученні про Ісуса Христа. Різний характер христологічних доктрин протестантських богословів, на нашу думку, зумовлений 
методами тлумачення Святого Письма. Лютеранська христологія послуговується алегоричним методом роз'яснення, властивого Олександрійській екзегетичній школі. Натомість цвінгліанство орієнтувалося на методологію Антиохійської школи, тому крім буквально-історичної інтерпретації Святого Письма, вони використовували споглядальний та топологічний метод екзегетики. За допомогою першого, розкривався духовний зміст біблійного тексту, а другий метод вживався для морального повчання віруючих. Важливо також звернути увагу, що основою формування христологічних уявлень лютеранства послужило августинівське вчення про Христа. Христологічні погляди Цвінглі, на думку більшості дослідників, зароджувалися під впливом ідей Томи Аквінського та Еразма Ротердамського.

Вплив різноманітних філософських та теологічних концепцій на формування релігійних поглядів У. Цвінглі проходив впродовж 20-х pp. XVI ст. й остаточно закріпилися у програмних документах швейцарського реформатора. Ідейні засади цвінгліанства знайшли своє відображення у "67-и тезах" Цюріхського диспуту та праці "Про істинну та хибну віру", де Цвінглі виклав головні положення свого вчення. Аналіз теологічних роздумів реформатора вказує на тотожність багатьох аспектів сотеріології із лютеранським вченням, насамперед, у доктрині передвизначеності. Однак, у христологічній проблематиці між протестантськими богословами намітилися глибокі розбіжності. Свідченням цього $\epsilon$ диспут між Цвінглі і Лютером протягом 1527-1528-х pp., під час якого яскраво вимальовується христологія швейцарського реформатора. Цвінглі категорично спростовував думку Лютера про наявність божественної властивості всюдисущості в людській природі. Причина цього заперечення була закладена в способі іпостасного з'єднання Божественної і людської природи в Христі, які були поставлені Лютером на один рівень. Цвінглі не погоджувався із використанням принципу "взаємоспілкування природних властивостей", вважаючи, що він розглядає сутність як абстрактне поняття й нівелює спосіб формулювання богословської думки. Тому, на думку швейцарського реформатора, уявлення Лютера про людську природу, яка одночасно перебуває на небесах і землі, неодмінно призведе до докетизму [10: 84].

У христологічній доктрині Цвінглі чітко розмежовуються Божественна і людська природа Христа в дусі середньовічної схоластики. Важливо зауважити, що в межах схоластичної теології домінувала думка про тіло Христа, яке перебуває на небесах у визначеному місці, це дало підставу Томі Аквінському сформулювати концепцію передвизначеності. Послуговуючись означеними свідченнями, Цвінглі заперечував присутність божественної частки лише у людській природі Христа. Така позиція швейцарського реформатора дозволила деяким дослідникам побачити взаємозв'язок із вченням Несторія у межах формули Халкидонського оросу. На нашу думку, головна розбіжність христологічних поглядів двох реформаторів полягала в осмисленні одкровення Бога. У гносеологічному аспекті Лютер розмежовує об'явленого Бога в людському тілі ("Deus revelatus") та невідомого Бога ("Deus absconditus") [10: 85-86]. На основі віршів Святого Письма: "Бо вгодно було, щоб у Нім перебувала вся повнота" (Колосян 1:19) та "... Хто бачив Мене, той бачив Отця..." (Івана 14:9), - Лютер формулює свою христологію: повнота Бога присутня в Ісусі не лише після Його воскресіння і вознесіння, але $\mathbf{3} 3$ моменту Його втілення. Такий підхід послужив роз'ясненням присутності Христа в євхаристії, який категорично відкидався Цвінглі. Вирішальним для Лютера $є$ не спосіб розуміння реальної присутності, але сам факт, що визнається. Однак, наявність абсолютної єдності Христа на Тайній вечері лютеранською церквою не пояснюється через відсутність роз'яснення у Святому Письмі. Христологічну доктрину в такому формулюванні Цвінглі не зміг прийняти.

Пневматичний характер христології Цвінглі виражається співвідношенням Божественної та людської природи Христа, завдяки чому Він став посередником між Богом та людьми. Перебуваючи під впливом христоцентризму Павла і послуговуючись ідеями Томи Аквінського, протестантський теолог вважав, що в Христі проявилася воля Бога для спасіння людства. У христологічній доктрині виразником цієї волі був Святий Дух, Який свідчив людям про Отця, Сина і всю істину, очищав та освячував грішників, щоб підготувати до життя в присутності Бога. Однак, на відміну від католицького чи православного розуміння Святого Духу як Божої сили в дії, на думку реформатора, Він не змінює світу і присутній лише в мисленні та серці людини. Святий Дух асоціюється з Христом, Який освітлює кожну людину і життя в Христі. Таким чином, Цвінглі, на відміну від Лютера, вибудовував сотеріологію у контексті спасіння всіх людей, а не конкретно вибраних. Головною умовою спасіння, за його вченням, було доброчинне життя.

Незважаючи на подібність поглядів цвінгліанства і лютеранства на виправдання, тлумачення цього аспекту богословами було різним. На відмінну від Лютера, який акцентував на зобов'язаннях Бога перед людиною, Цвінглі розглядав Писання як кодекс моральних обов'язків, головне призначення яких наслідувати земне життя Христа [5: 141-142]. Ця думка активно розвивається у доктрині виправдання вірою, в якій швейцарський реформатор, надає пріоритет ідеї морального оновлення над спасінням. Тому в інтерпретації Цвінглі, Христос постає у зовнішньому моральному образі.

Важливе значення у сотеріологічному вченні Цвінглі відіграє доктрина провидіння, де спасіння людини залежить виключно від Бога. Саме провидіння Цвінглі пояснює як форму спасіння за милістю Бога, а не за людськими вчинками. Звідси виникає парадоксальна ситуація, яку реформатор трактує на основі слів апостола Павла, що божественний вибір може випасти на грішну людину, яка своїми 
земними справами скомпрометувала себе перед Богом [11:488-492]. Цвінглі був переконаний, що спасіння людини було передвизначене Богом до ії народження [11: 511].

Розходження у різних аспектах христології між Лютером і Цвінглі особливо посилилося після твердження німецького реформатора, що таїнства це лише спосіб підтвердження віри, а й однин із засобів донесення свідоцтва, на яке людина відповідає як на проповідь. Однак, критикуючи католицизм, Лютер не відкинув формалізму в сотеріології, вчення про благодать і ії дію на волю людини. У результаті такого підходу, впродовж усього часу існування лютеранства, постійно можна спостерігати зміни в їх поглядах: "Так питання про суть священства досі не вирішене в лютеранинові, після того, як воно було поставлене в XVI ст." [12:3]. Лютер вважав, що між старозавітними символами і новозавітними Таїнствами немає різниці, людина виправдовується лише вірою: "Усе Писання складається 3 приписів і обіцянок: приписи гамують гордих, обіцянки підтримують пригнічених. Проте було б доречним обіцянки називати таїнствами, сполученими зі символами" [13: 68].

На нашу думку, головна розбіжність поглядів протестантських реформаторів у визначенні сутності таїнства лежить у площині вчення про взаємне спілкування властивостей. У контексті цього яскравим прикладом є диспут між Лютером і Цвінглі про присутність Тіла Христа в Євхаристії. Лютер завжди наголошував на єдності природ Христа, тому спілкування властивостей було реальним i чітко визначеним. Таким чином, Христос реально присутній у Євхаристії, завдяки божественній властивості всюдисущості в Його людській природі. Натомість Цвінглі вважав, що Тіло Христа перебуває лише на небі, а в Євхаристії Він присутній лише в спогляданні віри. Принцип взаємного спілкування властивостей для швейцарського реформатора відображався в образному мисленні. Головна суть дискусійного питання полягає в тому, як потрібно осмислити обожнення людської природи в Христі, виходячи із поглядів протестантських богословів. Якщо обожнення реальне, це призводить до поглинання людської природи Божественною, спростовуючи єдиносущість Христа 3 людиною. Якщо єдиносущість зберігається, тоді спасіння як реальне обожнення неможливе. Відповідь на це запитання ні Лютер, ні Цвінглі не надали.

На думку Цвінглі, значення таїнства причастя у вченні Лютера зводилося в уявлення про те, що тілесне споживання може допомогти врятувати душу людини. Святе Причастя є таїнством спокути смертю Христовою, тому для тих, хто праведно, достойно і з вірою приймає Його, хліб - це Причастя Тіла Христового, а чаша - Причастя Крові Христової. Тіло Христове дається, приймається і з'їдається на Вечері лише небесним і духовним чином, а засобом цього є віра. Лютеранська церква стверджує, що таїнство Вечері Господньої не слід зберігати, переносити, возвеличувати або робити предметом поклоніння. У контексті тлумачення таїнства євхаристії Лютер стверджував, що хліб і вино не перетворюються у "тіло і кров" Христа, але Він нібито присутній у таїнстві причастя. Міркування про таїнства як загальний елемент обрядовості для душі та тіла людини є однією із фундаментальних частин лютеранського вчення, яке було засуджене не лише різними протестантськими церквами, а й лютеранськими послідовниками.

Висновки. Таким чином, ортодоксальна лютеранська христологія вибудовувалася на твердженні "конечне може вмістити нескінченне" ("finitum capax infiniti"). Така антитеза визначила розвиток протестантської христології протягом тривалого часу, при цьому особливо наголошувалося на реальності двох Його природ. Причому ключові відмінності торкалися понятійно-категоріального апарату не лише способу і стану їх з'єднання, а також факту взаємодії однієї природи з іншою. Протиставлення двох христологічних систем призвело до послаблення біблійного образу земного Ісуса у протестантській теології. У зв'язку з цим трансформація христологічної доктрини протестантизму торкнулася змін принципу "спілкування властивостей" ("communicatio idiomatum") на концепцію "спілкування благодаті" ("communicatio gratiarum").

\section{СПИСОК ВИКОРИСТАНИХ ДЖЕРЕЛ ТА ЛІТЕРАТУРИ}

1. Нічик В. Громади антитринітаріїв на Україні та їх ідеологія / В. М. Нічик // Гуманістичні і реформаційні ідеї на Україні [під. ред. Нічик В. М., Литвинов В. Д., Стратій Я. М.]. - К. ; Наукова думка, 1991. - С. 64-128.

2. Головащенко С. Історія християнства : курс лекцій / С. Головащенко. - К. : Либідь, 1999. - 352 с.

3. Санников С. Двадцать веков христианства. Второе тысячелетие / С. В. Санников // Учебное пособие по истории християнства : в 2-х т. - Одеса : Богомыслие, 2001. - Т. 2. - 700 с.

4. Лютер М. 95 тезисов / М. Лютер ; Сост., вступит. ст., примеч., коммент. И. Фокина ; Пер. с нем. И. Каркалайнен. - СПб. : Роза мира, 2002. - 720 с.

5. Маграт А. Богословская мысль Реформации : научно-популярная литература / А. Маграт; Пер. В. В. Петлюченко. - Одесса : Богомыслие, 1994. - 316 с.

6. Кураев А. Протестантам о православии / Диакон Андрей Кураев. - М. : Изд-во Моск. Подворья СвятоТроиц. Сергиевой Лавры, 1999. - 267 с.

7. Лютер Мартин Время молчания прошло : Избранные произведения 1520-1526 гг. / Лютер Мартин ; Пер. с нем. - Харьков : Око, 1994. - 352 с.

8. Каспер В. Ісус Христос / В. Каспер ; пер. Н. Вельбовець. - К. : Дух і літера, 2002. - 427 с. 
9. Декрет об оправдании / Христианское вероучение: Догматические тексты учительства церкви III-XX вв. ; [отв. ред. о. Пьер Дюмулен; пер. с фр. Н. Соколовой, Ю. Куркиной]. - Санкт-Петербург : Издательство св. Петра, 2002. - С. 345-360.

10. Зассе Г. Сие есть Тело Мое / Германн Зассе. Перевод на русский язик: Валерий Володин. М.: Фонд "Лютеранское наследие", 2009. - 251 с.

11. Цвинги У. Богословские труды: [пер. с нем.] / Ульрих Цвингли ; [ред. А. С. Джанумов. - 3-е изд.]. Москва : Икар, 2005. - 556 с.

12. Маркелов Д. Протестантские таїнства : История, теология, семиотика / Д. М. Маркелов. - Тверь : Герс, 1999. -55 c.

13. Теста Б. О таинствах Церкви / Б. Теста. - М. : Христианская Россия, 2002. - 352 с.

\section{REFERENCES (TRANSLATER \& TRANSLITERATED)}

1. Nichyk V. Gromady antytrynitariiv na Ukraini ta yikh ideologiia [Communities of Anti-Trinitarians in Ukraine and Their Ideology] / V. M. Nichyk // Gumanistychni i reformacijni idei na Ukrayini [Humanistic and Reformation Ideas in Ukraine] [pid. red. Nichyk V. M., Lytvynov V. D., Stratij Ya. M.]. - K. : Naukova dumka, 1991. - S. 64 128.

2. Golovashhenko S. Istoriya khrystyianstva : Kurs lektsii [History of Christianity : Course of Lectures] / S. Golovashhenko. - K. : Lybid', 1999. - 352 s.

3. Sannikov S. Dvadtsat' vekov khristianstva. Vtoroe tysiacheletie [Twenty Centuries of Christianity. Second Millennium] / S. V. Sannikov // Uchebnoe posobie po istorii hristianstva : v 2-h t. [Textbook on the History of Christianity: in 2 Volumes]. - Odesa : Bogomyislie, 2001. - T.2. - $700 \mathrm{~s}$.

4. Lyuter M. 95 tezisov [95 Theses] / M. Lyuter; Sost., vstupit. st., primech., komment. I. Fokina; Per. s nem. I. Karkalainen. - SPb. : Roza mira, 2002. - 720 s.

5. Magrat A. Bogoslovskaia mysl' Reformatsi i: nauchno-populiarnaya literatura [The Reformation Theological Thought: Popular Science Literature] / A. Magrat ; Per. V. V. Petlyuchenko. - Odessa : Bogomyislie, 1994. - $316 \mathrm{~s}$.

6. Kuraev A. Protestantam o pravoslavii [To Protestants about Orthodoxy] / Diakon Andrey Kuraev. - M. : Izd-vo Mosk. Podvorya Svyato-Troits. Sergievoy Lavryi, 1999. - 267 s.

7. Lyuter Martin Vremia molchaniia proshlo : Izbrannyie proizvedeniia 1520-1526 gg. [The Time of Silence Has Passed : Selected Works of 1520-1526] / Per. s nem. - Harkov : Oko, 1994. - 352 s.

8. Kasper V. Isus Khrystos [Jesus Christ] / V. Kasper ; per. N. Vel'bovets'. - K. : Dukh i litera, 2002. - 427 s.

9. Dekret ob opravdanii [Decree of Excuse] / Hristianskoe verouchenie : Dogmaticheskie teksty uchitel'stva tserkvi III-XX vv. ; [otv. red. o. Per Dyumulen; per. s fr. N. Sokolovoi, Yu. Kurkinoi]. - Sankt-Peterburg : Izdatelstvo sv. Petra, 2002. - S. 345-360.

10. Zasse G. Sie est Telo Moe [This is My Body] / Germann Zasse. - Perevod na russkii yazyk : Valeriy Volodin. M. : Fond "Lyuteranskoe nasledie", 2009. - $251 \mathrm{~s}$.

11. Tsvingi U. Bogoslovskie trudy : [per. s nem.] [Theological Works : (Trans. from German)] / Ulrikh Tsvingli ; [red. A. S. Dzhanumov. - 3-e izd.]. - Moskva : Ikar, 2005. - $556 \mathrm{~s}$.

12. Markelov D. Protestantskie tainstva : Istoriya, teologiya, semiotika [Protestant Sacraments : History, Theology, Semiotics] / D. M. Markelov. - Tver' : Gers, 1999. - 55 s.

13. Testa B. O tainstvakh Tserkvi [About the Sacraments of the Church] / B. Testa. - M. : Hristianskaia Rossiia, 2002. $-352 \mathrm{~s}$.

\section{Соколовский О. Л. Христологические концепции в учениях лютеранского и цвинллианского течений.}

В статье исследовано основные положения христологических доктрин лютеранства и цвинглианства, важно указать их воздействие на дальнейшее развитие учения об Иисусе Христе в рамках других течений раннего протестантизма. Доведено, что главным источником лютеранской христологии является доктрина оправдания верой, которая раскрывает сотериологию протестантизма. В ивинглианстве учение об Иисусе Христе находится в плоскости сотериологии, которая христоцентрически направлена, а также концепции предопределенности.

Ключевые слова: христология, сотериология, эсхатология, лютеранство, иявинлианство, протестантизм, триадология.

\section{Sokolovsky O. L. Christological Concepts in the Teachings of the Lutheran and Zwinglian Movements.}

The key positions of early Christian Christology were reflected in the systematic theological doctrine of the identity of Jesus Christ of the Roman Catholic and Orthodox churches. However, under the conditions of the reform processes in Europe and the formation of capitalist relations, the main provisions of Christology were

transformed into the theology of Protestantism, which covers a large number of independent religions. According to the article the theory of early Protestant currents in a concise form was based on two general postulates: the source of faith - the Scriptures; the salvation of man depends only on faith. This led to the domination in Protestantism, as opposed to the dogmatic theology of Catholicism and Orthodoxy, a historicalcritical way of thinking, within which thinkers were cautious about tradition and experience. In this context, it is important to distinguish between denominational forms of Christology in Protestant dogmatic systems. Most 
Protestants share the general Christian attitudes about the triadology and Jesus Christ as a God-man, but deny the Catholic approach to understanding the mystery of Jesus Christ. The orthodox Lutheran Christology opposed the Calvinist statement "finitum non estcapax infiniti" to the opposite principle "finitum captain infiniti". This antithesis defined the development of Protestant Christology for a long time, with a particular emphasis on the reality of its two natures. Moreover, the key differences concerned the conceptual-categorical apparatus not only with the method and the state of their connection, but also the fact of the interaction of one nature with another. The opposition of two Christian systems led to the weakening of the biblical image of earthly Jesus in Protestant theology. To prevent the development of such a process, scientific approaches to balancing the state of increase and the decline of Christ, which provoked acute Christological discussions, were used. In this regard, the transformation of the Christian doctrine of Protestantism affected the changes in the principle of "communicating properties" to the concept of "communion of grace".

Key words: Christology, Soteriology, eschatology, Lutheranism, Zwinglianism, Protestantism, triadology. 